\title{
The flavonoid rutin induces astrocyte and microglia activation and regulates TNF-alpha and NO release in primary glial cell cultures
}

\author{
A. R. Silva • A. M. Pinheiro • C. S. Souza • \\ S. R. V.-B. Freitas - V. Vasconcellos $\cdot$ S. M. Freire • \\ E. S. Velozo • M. Tardy • R. S. El-Bachá • \\ M. F. D. Costa $\cdot$ S. L. Costa
}

Received: 10 November 2006 / Accepted: 18 April 2007 / Published online: 5 June 2007

(C) Springer Science + Business Media B.V. 2007

\begin{abstract}
Astrocyte and microglia cells play an important role in the central nervous system (CNS). They react to various external aggressions by becoming reactive and releasing neurotrophic and/or neurotoxic factors. Rutin is a flavonoid found in many plants and has been shown to have some biological activities, but its direct effects on cells of the CNS
\end{abstract}

A. R. Silva • A. M. Pinheiro $\cdot$ C. S. Souza

S. R. V.-B. Freitas - V. Vasconcellos • R. S. El-Bachá •

M. F. D. Costa $\cdot$ S. L. Costa $(\triangle)$

Laboratório de Neuroquímica e Biologia Celular,

Departamento de Biofunção, Instituto de Ciências da

Saúde, Universidade Federal da Bahia (UFBA),

Salvador, Brazil

e-mail: costasl@ufba.br

\section{S. M. Freire}

Laboratório de Imunologia, Departamento de Biointeração, Instituto de Ciências da Saúde, Universidade Federal da Bahia (UFBA),

Salvador, BA 40.110-100, Brazil

\section{E. S. Velozo}

Laboratório de Pesquisa em Matéria Médica, Faculdade de Farmácia, UFBA Universidade Federal da Bahia,

Salvador, Brazil

M. Tardy

Faculté de Médicine, Val-de-Marne, Université Paris XII, Créteil, France have not been well studied. To investigate its potential effects on CNS glial cells, we used both astrocyte primary cultures and astrocyte/microglia mixed primary cell cultures derived from newborn rat cortical brain. The cultures were treated for $24 \mathrm{~h}$ with rutin (50 or $100 \mu \mathrm{mol} / \mathrm{L})$ or vehicle $(0.5 \%$ dimethyl sulfoxide). Mitochondrial function on glial cells was not evidenced by the MTT test. However, an increased lactate dehydrogenase activity was detected in the culture medium of both culture systems when treated with $100 \mu \mathrm{mol} / \mathrm{L}$ rutin, suggesting loss of cell membrane integrity. Astrocytes exposed to $50 \mu \mathrm{mol} / \mathrm{L}$ rutin became reactive as revealed by glial fibrillary acidic protein (GFAP) overexpression and showed a star-like phenotype revealed by Rosenfeld's staining. The number of activated microglia expressing OX-42 increased in the presence of rutin. A significant increase of nitric oxide (NO) was observed only in mixed cultures exposed to $100 \mu \mathrm{mol} / \mathrm{L}$ rutin. Enhanced TNF $\alpha$ release was observed in astrocyte primary cultures treated with $100 \mu \mathrm{mol} / \mathrm{L}$ rutin and in mixed primary cultures treated with 50 and $100 \mu \mathrm{mol} / \mathrm{L}$, suggesting different sensitivity of both activated cell types. These results demonstrated that rutin affects astrocytes and microglial cells in culture and has the capacity to induce $\mathrm{NO}$ and $\mathrm{TNF} \alpha$ production in these cells. Hence, the impact of these effects on neurons in vitro and in vivo needs to be studied. 
Keywords Astrocyte - Flavonoid · Microglia · NO . Rutin $\cdot$ TNF- $\alpha$

$\begin{array}{ll}\text { Abbreviations } \\ \text { APC } & \text { astrocyte primary culture } \\ \text { BBB } & \text { blood-brain barrier } \\ \text { CNS } & \text { central nervous system } \\ \text { DMF } & \text { dimethylformamide } \\ \text { ELISA } & \text { enzyme-linked immunosorbent assay } \\ \text { GFAP } & \text { glial fibrillary acidic protein } \\ \text { LDH } & \text { lactate dehydrogenase } \\ \text { MPC } & \text { mixed primary culture } \\ \text { MTT } & \text { 3-(4,5-dimethylthiazol-2-yl)-2, } \\ & \text { 5-diphenyltetrazolium bromide } \\ \text { PAGE } & \text { polyacrylamide gel electrophoresis } \\ \text { SDS } & \text { sodium dodecyl sulfate } \\ \text { THF } & \text { tetrahydrofuran } \\ \text { TNF } & \text { tumor necrosis factor }\end{array}$

\section{Introduction}

In the central nervous system (CNS) astrocytes and microglia are cells of the glial family, which plays an important role in brain homeostasis, detoxification and immune response against chemical, infectious or traumatic challenges (Aschner 1998). In vitro and in vivo studies have clearly demonstrated that these cells react to external injuries by undergoing activation, a phenomenon known as gliosis. Reactive gliosis is characterized by the presence of hypertrophic astrocytes and the intracellular accumulation of the major component of their gliofilaments, the glial fibrillary acidic protein (GFAP). Proliferation of microglial cells (microgliosis) and in some cases astrocytes (astrogliosis) (Ridet et al. 1997; Aschner 1998; Aloisi 2001) is also observed. Activated glial cells can secrete a variety of factors with pro-inflammatory and neurotoxic properties including cytokines such as TNF $\alpha$, fatty acid metabolites, and free radicals such as nitric oxide (NO) (Raivich et al. 1999; Aloisi 2001).

Flavonoids are secondary metabolites of a large number of plants, protecting them against the damaging effects caused by UV-radiation and microbial infection (Havsteen 2002). They have been adopted in popular medicine. The flavonoids naringenin, quercetin and hispidulin cross the blood-brain barrier (BBB) and studies employing rat in situ brain perfusion have revealed the presence of these compounds in different brain regions (Takasato et al. 1984; Youdim et al. 2004). Moreover, a study has reported the presence of epicatechin glucuronide and 3'-O-methylepicatechin glucuronide in rat brain tissue, formed after oral ingestion of epicatechin (Schroeter et al. 2002). Rutin $\left(3,3^{\prime}, 4^{\prime}, 5,7\right.$-pentahydroxyflavone-3-rutinoside) is the quercetin rutinoside. Since rutinosides, such as the cyanidin-3-rutinoside, showed measurable permeability across an in vitro BBB model (Youdim et al. 2003), it may be suggested that rutin can also cross the BBB. The flavonoid rutin and its derivatives were used intraperitoneally in doses of $200 \mathrm{mg} / \mathrm{kg}$, a concentration that corresponds to $10 \%$ of the $\mathrm{LD}_{50}$ in rats (Lambev et al. 1980a,b). Rutin has been adopted in the treatment of senile cerebral defects (Youdim et al. 2004), to alleviate the micro trauma of the tissue; it also has a pharmacological application in strengthening veins, thus preventing bleeding (Raven et al. 2001; Janbaz et al. 2002). We have observed that rutin is able to inhibit the proliferation of a human glioma cell line (data unpublished). Recently, the therapeutic parenteral use of this flavonoid to enhance the efficacy of antibiotics has been protected by patent (Higuchi et al. 2006). However, its potential effects upon possible target cells in the brain have not been investigated. Since the parenteral use of rutin can lead to increased plasma levels, we hypothesized that at high pharmacological concentrations it could interfere in the biological activity of glial cells, which are directly involved in brain detoxification and control of brain functions. In this study, highly enriched astroglial primary cultures and mixed populations of astrocytes and microglial cells obtained from newborn rat cortical regions were cultured in the presence of rutin. Activation, cytotoxicity and release of oxidative and inflammatory factors were investigated.

\section{Experimental procedures}

\section{Cell cultures}

One-day-old Wistar rat pups used in this study were obtained from the animal house facility of the Instituto de Ciências da Saúde, UFBA. Astrocyte primary cultures (APC) were prepared according to 
Cookson and Pentreath (1994), as described (Silva et al. 2006). Briefly, cerebral hemispheres of newborn Wistar rat pups were isolated aseptically and meninges were removed. Neopallia were dissected out and then gently forced through a sterile $75 \mu \mathrm{m}$ Nitex mesh. Cells were suspended in Dulbecco's Modified Eagle's Medium (DMEM, Cultilab, SP, Brazil), supplemented with $100 \mathrm{UI} / \mathrm{ml}$ penicillin $\mathrm{G}$, $100 \mu \mathrm{g} / \mathrm{ml}$ streptomycin, $2 \mathrm{mmol} / \mathrm{L}$ L-glutamine, $0.011 \mathrm{~g} / \mathrm{L}$ pyruvate, and $10 \%$ fetal calf serum (Cultilab), seeded on polystyrene culture dishes (TPP, Trasadingen, Switzerland), and incubated in a humidified atmosphere with $5 \% \mathrm{CO}_{2}$ at $37^{\circ} \mathrm{C}$. After 2 days, cultures were shaken for $5 \mathrm{~min}$ and the medium was changed to remove microglial cells. To obtain the mixed primary cultures (MPC), the same protocol was used except that cultures were not shaken to remove other cell types. As determined by immunocytochemistry for the protein GFAP, APC presented about $95 \%$ of GFAP-labeled astrocytes, and about $1.3 \%$ of OX42-positive microglia cells; MPC presented about $85 \%$ of GFAP-labeled astrocytes, and about $3.5 \%$ of OX-42 positive microglia cells.

Drug and treatment

The flavonoid rutin was extracted from Dimorphandra mollis seed by recrystallization in tetrahydrofuran (THF), according to Merck S.A. procedures in LAPEMM-FFar-UFBA. The methanolic extract obtained from the broad beans of Dimorphandra mollis was fractionated into $n-\mathrm{BuOH}$, and $\mathrm{H}_{2} \mathrm{O}$ layers through solvent fractionation. Repeated silica gel column chromatography of the $n$-BuOH layer and recrystallization from THF afforded the flavonol glycoside rutin ( $99 \%$ of purity). Rutin (quercetin3-O-rhamnoglucoside) was identified on the basis of its UV (in ethanol), IR ( $\mathrm{KBr}$ film) and NMR $\left({ }^{1} \mathrm{H}\right.$ and ${ }^{13} \mathrm{C}$, in MeOD and DMSO- $\mathrm{d}_{6}$, respectively) spectral data, which were compared with those found in the literature (Markhan 1982). For treatments, rutin was dissolved in dimethyl sulfoxide (DMSO, Sigma, St. Louis, MO, USA) at a concentration of $20 \mathrm{mmol} / \mathrm{L}$, and stored in the dark at $-20^{\circ} \mathrm{C}$.

Cells were treated when they attained confluence, 18 days after they were seeded. At the time of the experiment, cells were trypsinized and counted, and $5 \times 10^{5}$ cells were plated per dish of diameter of
$40 \mathrm{~mm}$. After $48 \mathrm{~h}$, the medium was changed and rutin was added directly at final concentrations of 50 and $100 \mu \mathrm{mol} / \mathrm{L}$, for $24 \mathrm{~h}$. The negative control group was treated with DMSO diluted in the culture medium at the higher equivalent volume used in the treated group $(0.5 \%)$, and showed no significant effect on analyzed parameters compared to cells that did not receive the diluent.

Cytotoxicity and cell membrane integrity assays

Rutin was tested for its cytotoxicity toward glial cell cultures using the 3-(4,5-dimethylthiazol-2-yl)-2,5diphenyltetrazolium bromide (MTT; Sigma) test. The experiment was performed in 96 well plates (TPP) $\left(1.6 \times 10^{4}\right.$ cells/plate) after cells had become confluent (95\%). Cell viability was quantified by the conversion of yellow MTT to purple MTT formazan by mitochondrial dehydrogenases of living cells (Hansen et al. 1989). Control and treated cells were incubated with MTT at a final concentration of $1 \mathrm{mg} / \mathrm{ml}$ for $2 \mathrm{~h}$. Thereafter, cells were lysed with $20 \%(\mathrm{w} / \mathrm{v})$ sodium dodecyl sulfate (SDS), 50\% (v/v) dimethyl formamide (DMF) ( $\mathrm{pH} 4.7$ ), and plates were kept overnight at $37^{\circ} \mathrm{C}$ in order to dissolve formazan crystals. The optical density of each sample was measured at $490 \mathrm{~nm}$ with a Bio-Rad 550PLUS spectrophotometer. Three independent experiments were carried out with four replicate wells for each analysis. Results are shown as percentage viability of the treated groups relative to the control groups.

Membrane integrity was evaluated by measuring the lactate dehydrogenase (LDH) activity in culture medium of control and treated cells. Cells were treated with rutin for $24 \mathrm{~h}$ and the culture medium was then removed and the LDH activity (UI/L) was measured according to the manufacturer's protocol (Doles, Goiás, Brazil). Three independent experiments were carried out for each experimental point.

Cell morphology and protein expression

\section{Rosenfeld's staining and immunocytochemistry}

Morphological changes and cell activation were studied by analyzing the Rosenfeld's staining and the immunocytochemistry patterns for the proteins GFAP (for astrocytes) and OX-42 (for microglial cells). 
All glial cells, control and treated, seeded on $40 \mathrm{~mm}$ polystyrene culture dishes (TPP) were rinsed three times with PBS without $\mathrm{Ca}^{2+}$ and $\mathrm{Mg}^{2+}$ and fixed for $10 \mathrm{~min}$ with ice-cold methanol at $-20^{\circ} \mathrm{C}$.

For GFAP immunocytochemistry, fixed cells were incubated with rabbit polyclonal anti-GFAP (1/500 in PBS, Dako, Denmark) overnight and then with tetramethylrhodamine isothiocyanate-conjugated goat anti-rabbit IgG antibody (1/250 in PBS, Sigma) for $30 \mathrm{~min}$ at room temperature. Nuclear chromatin of fixed cells was stained with the fluorescent dye Hoechst 33258 (Sigma), at a final concentration of $5 \mu \mathrm{g} / \mathrm{ml}$ in PBS, for $10 \mathrm{~min}$ at room temperature in a dark chamber. Thereafter, cells were analyzed by fluorescent microscopy (Olympus BX70) and photographed. Ten randomized representative fields were analyzed in each case.

Microglial cell marking was achieved by immunocytochemistry against OX-42 in primary cultures. First, the endogenous peroxidase activity was blocked for 10 min with $3 \% \mathrm{H}_{2} \mathrm{O}_{2}$ in PBS. The cells were then incubated for $1 \mathrm{~h}$ with the mouse monoclonal antiOX-42 (CD11b/c) antibody (1:200 in PBS, Caltag, Burlingame, CA, USA). Then cells were incubated with goat anti-mouse IgG peroxidase-conjugated antibody (1:1000 in PBS, Zymed), for $1 \mathrm{~h}$. Microglial cells were labeled brown using a $0.3 \%$ of 4 -Cl-alphanaphthol/methanol solution diluted in PBS buffer (1:5) plus $\mathrm{H}_{2} \mathrm{O}_{2}(0.33 \mu \mathrm{l} / \mathrm{ml})$ and incubated at room temperature for $30 \mathrm{~min}$. To identify microglia and cell morphology, co-staining was performed by the protocol established by Rosenfeld (1947). The Rosenfeld's reagent $(1 \mathrm{ml})$ was added and incubated for $20 \mathrm{~min}$ at room temperature. Thereafter, the plates were rinsed with water, air dried, analyzed, and photographed in an optical phase microscope (Nikon TS-100) using a digital camera (Nikon E-4300). The number of immunoreactive cells was counted under the microscope using $20 \times$ magnification in a $0.29 \mathrm{~mm}^{2}$ field. Ten randomized representative fields were analyzed in each case, and the proportion of OX-42-positive cells was determined as the percentage of labeled cells relative to the total number of cells counted.

\section{Protein assay and western blot}

The expressions of GFAP, OX-42, and the more stable cytoskeletal protein vimentin were investigated by western immunoblot. After treatment, cells were rinsed twice with PBS, harvested, and lysed in 2\% (w/ v) SDS, $2 \mathrm{mmol} / \mathrm{L}$ EGTA, $4 \mathrm{~mol} / \mathrm{L}$ urea, $0.5 \%(\mathrm{v} / \mathrm{v})$ Triton X-100, $62.5 \mathrm{mmol} / \mathrm{L}$ Tris-HCl buffer ( $\mathrm{pH} 6.8$ ) supplemented with $0.1 \%(\mathrm{v} / \mathrm{v})$ of a cocktail of protease inhibitors (Sigma). Protein content was determined by a method adapted from Lowry et al. (1951) with a DC protein assay reagent kit (Bio-Rad, Hercules, CA, USA). For analysis, $10 \mu \mathrm{g}$ protein, prepared as described above, was loaded onto a discontinuous 4\% stacking and 8\% running SDSpolyacrylamide gel. Electrophoresis was performed at $200 \mathrm{~V}$ for $45 \mathrm{~min}$. Proteins were then transferred onto a polyvinylidene fluoride membrane (PVDF, Immobilon-P, Millipore), at $100 \mathrm{~V}$ for $1 \mathrm{~h}$. Equal protein loading was confirmed by staining the membranes with Ponceau red (Sigma). Thereafter, membranes were blocked for $1 \mathrm{~h}$ at room temperature in $20 \mathrm{mmol} / \mathrm{L}$ Tris-buffered saline ( $\mathrm{pH} 7.5$ ), containing $0.05 \%$ Tween 20 (TBS-T) and 5\% powdered skim milk. Subsequently, membranes were incubated with rabbit anti-GFAP (1:1000, Signet, Dedham, MA, USA) or mouse anti-vimentin $(1: 1000$, clone 3B4, Oxford Biotechnology, Oxford, UK) or mouse anti-OX-42 (1:100, Caltag) monoclonal antibodies for $1 \mathrm{~h}$, diluted in TBS-T containing $1 \%$ powdered skim milk. Conjugated alkaline phosphatase goat anti-rabbit $\operatorname{IgG}$ or goat anti-mouse IgG (1:5000 in TBS-T, Bio-Rad) was used as a secondary antibody. Immunoreactive bands were visualized using AP conjugated substrate kit (Bio-Rad) according to manufacturer's instructions. Quantification was obtained by scanning densitometry (ScanJet 4C, Hewlett Packard) of three independent experiments, and analyzed with Image $1.33 \mathrm{u}$ (Wayne Rasband, National Institutes of Health, USA). Antibody specificity and linearity of the densitometric analysis system was assessed by serial dilutions of total protein from cells in control conditions within a range of 5-20 $\mu \mathrm{g}$ of protein per lane.

$\mathrm{TNF} \alpha$ and NO production

TNF $\alpha$ was measured by ELISA sandwich in culture medium of glial cells, cultured in $40 \mathrm{~mm}$ diameter plates. The culture medium of three independent experiments was collected $24 \mathrm{~h}$ after the treatment from controls and experimental groups and the quantities of $\mathrm{TNF} \alpha$ were measured with rat $\mathrm{TNF} \alpha$ 
ELISA kit (BD biosciences, San Diego, CA), according to the manufacturer's instructions. Results are expressed as $\mathrm{pg} / \mathrm{ml}$.

The production of NO was assessed as nitrite $\left(\mathrm{NO}_{2}{ }^{-}\right)$accumulation in the culture medium of three independent experiments, using a colorimetric test based on Griess reagent (Wang et al. 2002). Samples $(50 \mu \mathrm{l})$ were collected after $24 \mathrm{~h}$ treatment. Equal volumes of culture medium and Griess reagent $(1 \%$ sulfanilamide, $0.1 \% \mathrm{~N}$-(1-naphthyl)ethylenediamine dihydrochloride, $2 \%$ phosphoric acid) were mixed. The mixture was incubated for $10 \mathrm{~min}$ at room temperature, and the absorbance at $550 \mathrm{~nm}$ was measured on a microplate reader (Bio-Rad 550PLUS Spectrophotometer). The concentrations of nitrite in the samples were determined based on a sodium nitrite standard curve $\left(\mathrm{NaNO}_{2}, 1.26-100 \mathrm{mmol} / \mathrm{L}\right)$.

\section{Statistical analysis}

Results are expressed as mean \pm standard deviation. One way ANOVA followed by the Student-NewmanKeuls test was used to determine the statistical differences among groups differing in only one parameter. Student's $t$-test was used to compare two groups. Values of $p<0.05$ were considered as significant.

\section{Results}

Effect of rutin on glial cell viability

Rutin did not apparently affect the mitochondrial function of these glial cells. As revealed by MTT test, no significant change in mitochondrial function was observed after $24 \mathrm{~h}$ treatment of the cells with $50 \mu \mathrm{mol} / \mathrm{L}$ or $100 \mu \mathrm{mol} / \mathrm{L}$ rutin when compared to the control (0.5\% DMSO) (Fig. 1a).

The LDH activity in the medium of glial cell cultures revealed no effects on membrane integrity of glial cells exposed to $50 \mu \mathrm{mol} / \mathrm{L}$ rutin (Fig. $1 \mathrm{~b}$ ). However, when cells were exposed to $100 \mu \mathrm{mol} / \mathrm{L}$ rutin, the levels of LDH activity in the culture medium increased significantly $(p<0.05)$. This effect was more important in astroglial cultures than in the mixed population. The exposure of the primary cultures for $24 \mathrm{~h}$ to the dilution vehicle (DMSO) in equivalent volume to the experimental concentrations did not show any
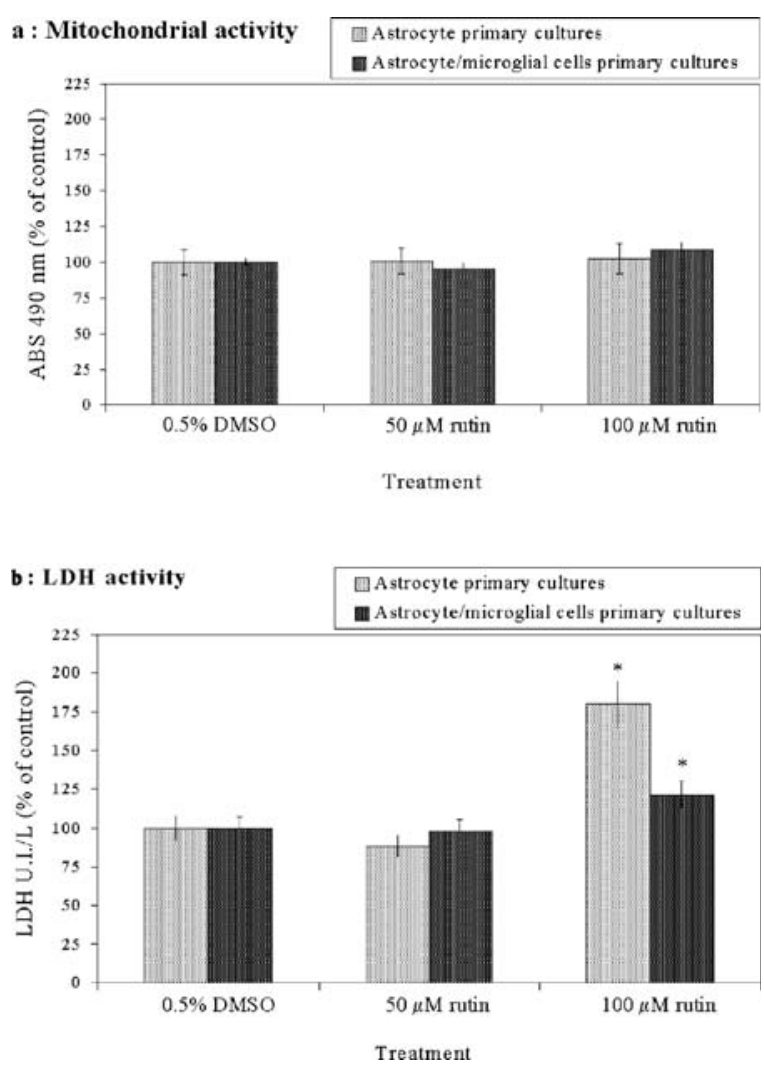

Fig. 1 Cytotoxicity assays on astrocyte and astrocyte/microglial cell primary cultures treated with the vehicle (DMSO $0.5 \%$ ) or rutin (50 and $100 \mu \mathrm{mol} / \mathrm{L})$, and evaluated at $24 \mathrm{~h}$ post treatment. (a) MTT test; (b) LDH activity in culture medium. Values for vehicle control samples $(0.5 \%$ DMSO) were set at $100 \%$; ${ }^{*} p<0.05$ compared with respective controls

significant alteration in the analyzed parameters, when compared with cultures that were not exposed to this solvent.

Effect of rutin on glial cell morphology and protein expression

The morphology and immunostaining patterns of cells treated with the vehicle DMSO $(0.5 \%)$ or with rutin (50 or $100 \mu \mathrm{mol} / \mathrm{L}$ ) for $24 \mathrm{~h}$ are shown in Figs. 2 and 4.

As shown by Rosenfeld's staining, astrocytes in the control cultures had a flat and polygonal phenotype (Fig. 2a). After $24 \mathrm{~h}$ of culture in the presence of $50 \mu \mathrm{mol} / \mathrm{L}$ rutin, astroglial cells had contracted cell bodies (Fig. 2b) and presented short and thick processes. In mixed cultures (Fig. $2 \mathrm{~d}-\mathrm{f}$ ), the astroglial basal layer in control conditions resembled that in purified astroglial cultures (Fig. 2d), whereas in 50 or 
Fig. 2 Rosenfeld's staining of astrocyte primary cultures $(\mathrm{a}-\mathrm{c})$ and immunocytochemistry for the protein OX-42 (arrows), with Rosenfeld's co-staining of astrocyte/microglial cell primary cultures $(\mathrm{d}-\mathrm{f}), 24 \mathrm{~h}$ post treatment. Cells were treated with the vehicle $0.5 \%$ DMSO (a, d), $50 \mu \mathrm{mol} / \mathrm{L}$ rutin $(\mathrm{b}, \mathrm{e})$, or $100 \mu \mathrm{mol} / \mathrm{L}$ rutin $(\mathrm{c}, \mathrm{f})$. Obj. $20 \times 0.70$, scale bar $=50 \mu \mathrm{m}$. This result is representative of three independent experiments

DMSO
(0.5\%)
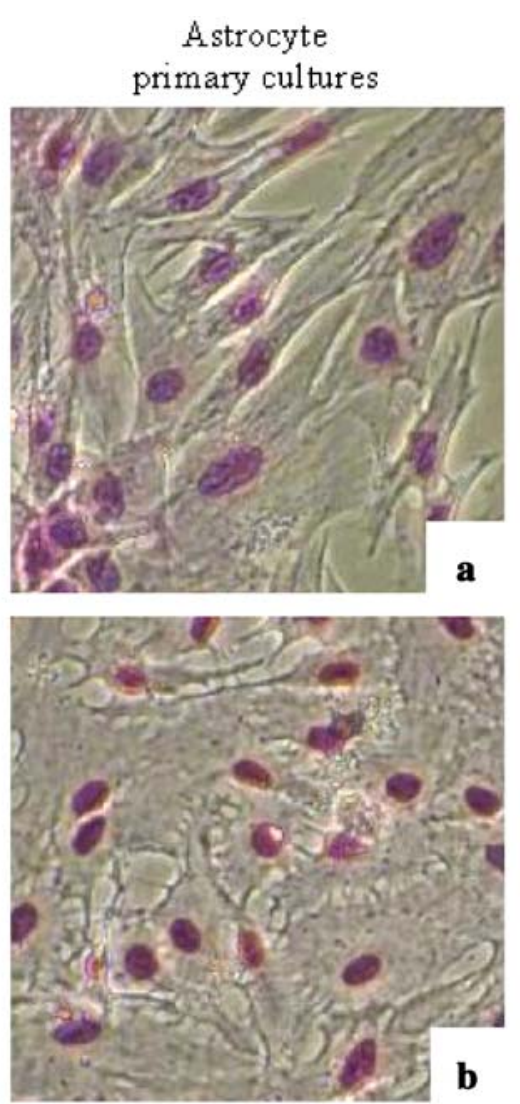

Rutin

(50 $\mu \mathrm{M})$

Rutin

$(100 \mu \mathrm{M})$

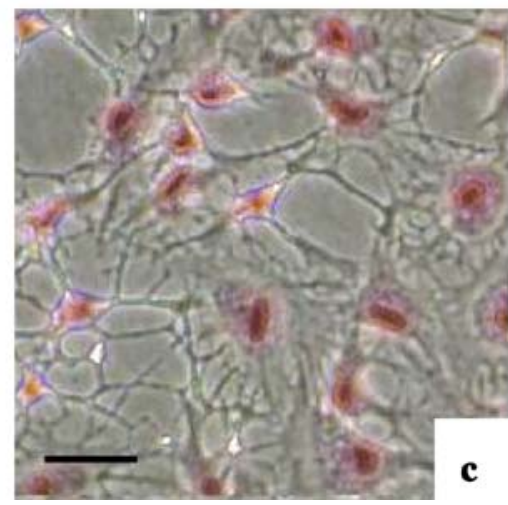

Astrocyte/microglial cell

primary cultures
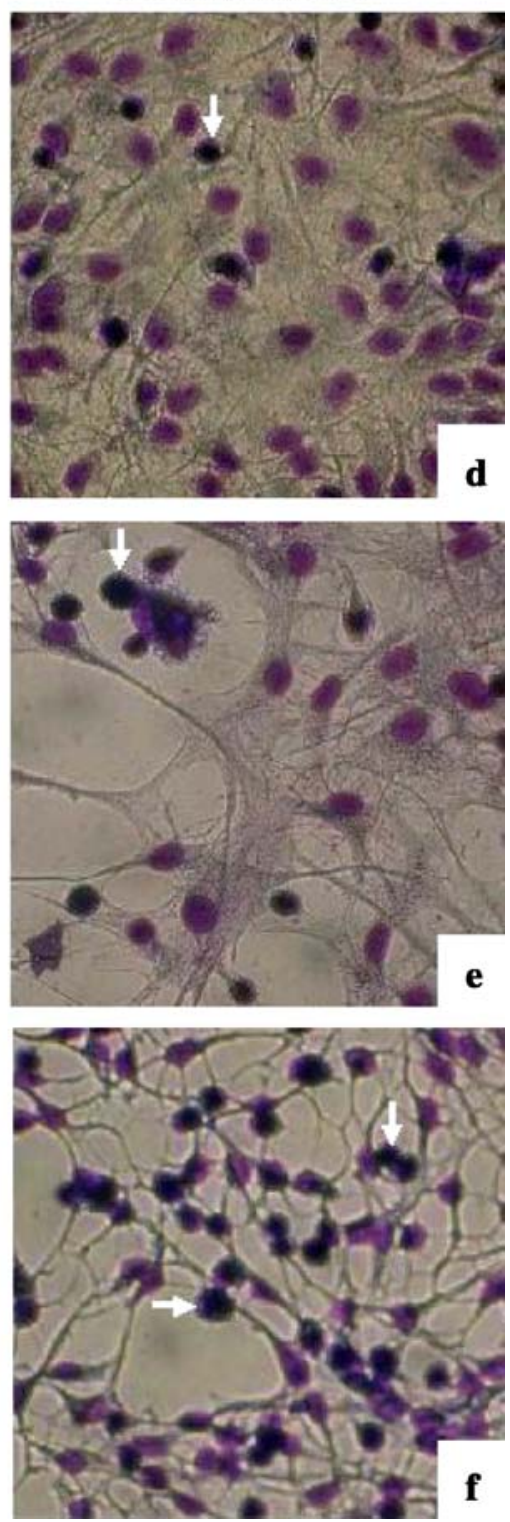

$100 \mu \mathrm{mol} / \mathrm{L}$ rutin-treated cultures the astrocyte morphological changes were amplified and more evident (Fig. 2e,f). In mixed primary cultures in the control conditions, the OX-42 staining revealed few dark, small, round microglial cells without any processes (Fig. 2d). However, in these cultures the number of OX-42-positive activated microglial cells increased significantly $(p<0.05)$ in the presence of 50 or $100 \mu \mathrm{mol} / \mathrm{L}$ rutin in a dose-dependent manner (Fig. 2e,f). Their number changed from 3.66\% $2.41 \%$ of the total cell population in control con- ditions to $11.53 \% \pm 2.98 \%$ and $19.06 \% \pm 9.43 \%$ when cultured in the presence of 50 and $100 \mu \mathrm{mol} / \mathrm{L}$ of rutin, respectively (Fig. 3). The immunostaining also revealed few OX-42-positive microglial cells on APC $(1.29 \% \pm 0.98 \%)$, and the proportion increased to $3.70 \% \pm 2.32 \%$ in cultures treated with $50 \mu \mathrm{mol} / \mathrm{L}$ rutin and significantly $(p<0.05)$ to $7.05 \% \pm 1.83 \%$ when cultures were treated with $100 \mu \mathrm{mol} / \mathrm{L}$ rutin (Fig. 3).

In astrocyte primary cultures, GFAP immunolabeling confirmed the astroglial polygonal phenotype, 


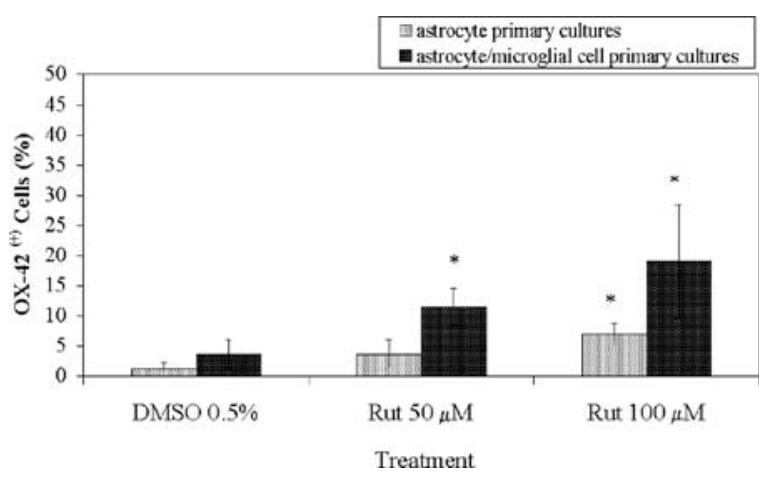

Fig. 3 Quantification of immunocytochemistry analysis of OX-42-positive cells performed in astrocyte primary cultures and in astrocyte/microglial cell primary cultures in control conditions (DMSO $0.5 \%$ ) or treated with 50 and $100 \mu \mathrm{mol} / \mathrm{L}$ rutin. ${ }^{*} p<0.05$, when compared with the control

with this protein present in both the cell body and the cell processes of more than $95 \%$ of the astroglial cell population (Fig. 4a). The same immunolabeling of the control astrocyte/microglia cell primary cultures revealed a similar pattern of GFAP staining with more than $85 \%$ of GFAP-positive astrocytes, but a significant proportion (around 14\%) of GFAP-negative cells (Fig. 4d). It also demonstrated the observed phenotypic changes toward a star-like GFAP-labeled astrocyte in the presence of rutin (Fig. 4c,d). This effect was amplified and more evident in mixed primary cultures, with a predominance of star-like shape in GFAP-positive cells (Fig. 4e,f). Hoechst staining of the nuclei showed regular, round nuclei with uniform chromatin staining in the controls, but more contracted nuclei in the treated cells.

The expression of OX-42, GFAP, and the more stable protein vimentin was also examined by western immunoblot (Fig. 5). The OX-42 immunodetection showed three immunoreactive bands of 156, 104, and $86 \mathrm{kDa}$ proteins, and its overexpression in protein extracts of both glial cell primary cultures treated with 50 or $100 \mu \mathrm{mol} / \mathrm{L}$ rutin. An increase in GFAP (49 kDa) levels in protein extracts from astrocyte primary cultures treated with $50 \mu \mathrm{mol} / \mathrm{L}$ rutin was also observed (Fig. 5a). Conversely, a decrease on GFAP expression was observed in the protein extracts from astrocyte/microglial cell primary cultures treated with 50 or $100 \mu \mathrm{mol} / \mathrm{L}$ rutin (Fig. 5b). The level of the more stable protein vimentin $(60 \mathrm{kDa})$ was not modified in glial cell primary cultures in any experimental conditions (Fig. 5a,b).

\section{Effect of rutin on $\mathrm{TNF} \alpha$ and $\mathrm{NO}$ production}

To investigate rutin interference on glial cell function, the release of two soluble compounds on culture medium was measured: the pro-inflammatory cytokine TNF $\alpha$, and the reactive neuromediator NO.

The ELISA for TNF $\alpha$, performed $24 \mathrm{~h}$ post treatment, indicated that in control conditions the basal level of $\mathrm{TNF} \alpha$ in the culture medium of astrocyte primary cultures (APC) was 107.6 $\pm 39.74 \mathrm{pg} / \mathrm{ml}$ (Table 1). When APC were exposed to $50 \mu \mathrm{mol} / \mathrm{L}$ rutin there was a reduction of TNF $\alpha$ release into the culture medium $(67.45 \pm 29.39 \mathrm{pg} / \mathrm{ml})$, but it was not statistically significant. On the other hand, a significant increase $(p<0.05)$ of TNF $\alpha$ levels in the culture medium $(161.79 \pm 32.73 \mathrm{pg} / \mathrm{ml})$ of cells treated with $100 \mu \mathrm{mol} / \mathrm{L}$ rutin was observed, compared with cells in control conditions. Compared with purified astrocyte primary cultures, the basal TNF $\alpha$ level of mixed primary cultures (MPC) was higher, and reached $614.89 \pm 33.6 \mathrm{pg} / \mathrm{ml}$. Exposure of MPC to 50 or $100 \mu \mathrm{mol} / \mathrm{L}$ rutin induced a significant increase $(p<$ $0.05)$ in the $\mathrm{TNF} \alpha$ levels released into the culture medium: $1565.79 \pm 21.12 \mathrm{pg} / \mathrm{ml}$ and $2336.76 \pm$ $54.75 \mathrm{pg} / \mathrm{ml}$, respectively.

In control conditions, the medium of primary glial cultures presented similar and very low levels of nitrite: $6.9 \pm 3.13 \mu \mathrm{mol} / \mathrm{L}$ for $\mathrm{APC}$, and $6.79 \pm 2.9 \mu \mathrm{mol} / \mathrm{L}$ for MPC (Table 1). No significant changes in nitrite levels were observed in the culture medium of astrocytes treated with 50 or $100 \mu \mathrm{mol} / \mathrm{L}$ rutin. However, $24 \mathrm{~h}$ treatment of the astrocyte/microglial cell primary cultures with this flavonoid at $100 \mu \mathrm{mol} / \mathrm{L}$ induced a very significant increase $(p<0.001)$ of nitrite production, with values reaching $44.54 \pm$ $9.79 \mu \mathrm{mol} / \mathrm{L}$.

\section{Discussion}

Among the major cell types of the CNS, astrocytes and microglial cells play an important role in brain homeostasis, detoxification, neuroprotection and immune response against toxicants, infections, or trauma (Coyle and Schwarcz 2000). Their activation may interfere with neuronal cell health and integrity (Coyle and Schwarcz 2000; Moises et al. 2002). Astroglial and microglial primary cultures have been used largely as models to evaluate their functions and their 
Fig. 4 GFAP immunocytochemistry with Hoechst33258 co-staining of nuclear chromatin, of astrocyte primary cultures $(\mathrm{a}-\mathrm{c})$ and astrocyte/microglial cell primary cultures (d-f), $24 \mathrm{~h}$ post treatment. Cells were treated with vehicle $0.5 \%$ DMSO (a, d), $50 \mu \mathrm{mol} / \mathrm{L}$ rutin $(\mathrm{b}, \mathrm{e})$, or $100 \mu \mathrm{mol} / \mathrm{L}$ rutin (c, f). Obj. $20 \times 0.70$, scale bar $=50 \mu \mathrm{m}$; arrows indicate examples of GFAPnegative cells. This result is representative of three independent experiments

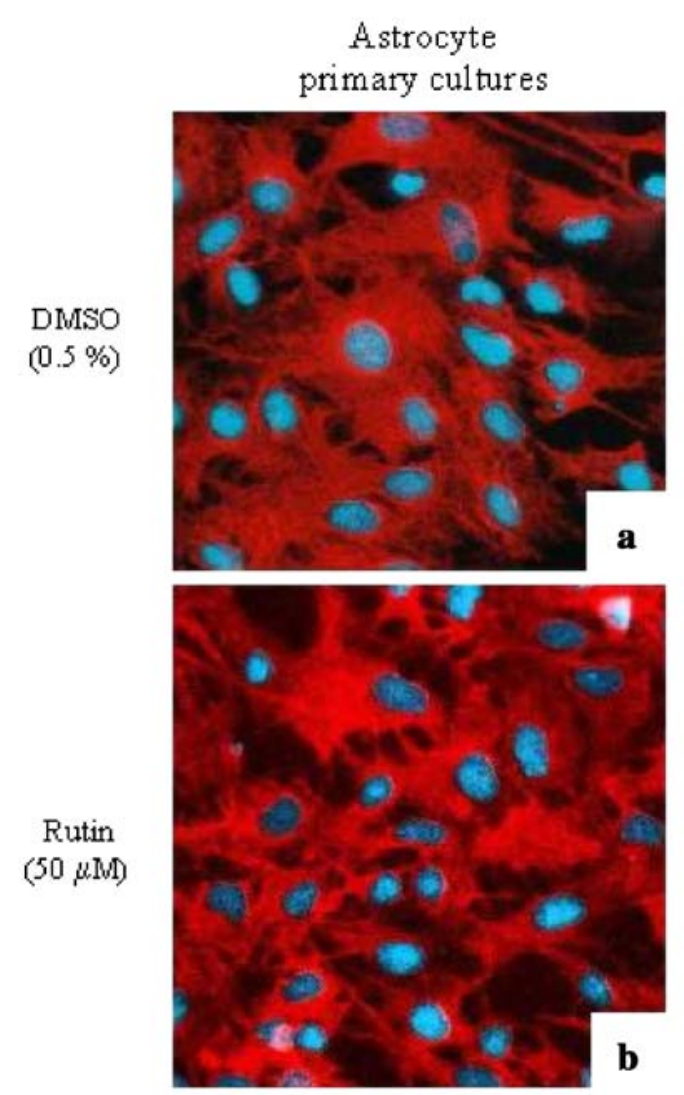

Astrocyte/microglial cell primary cultures
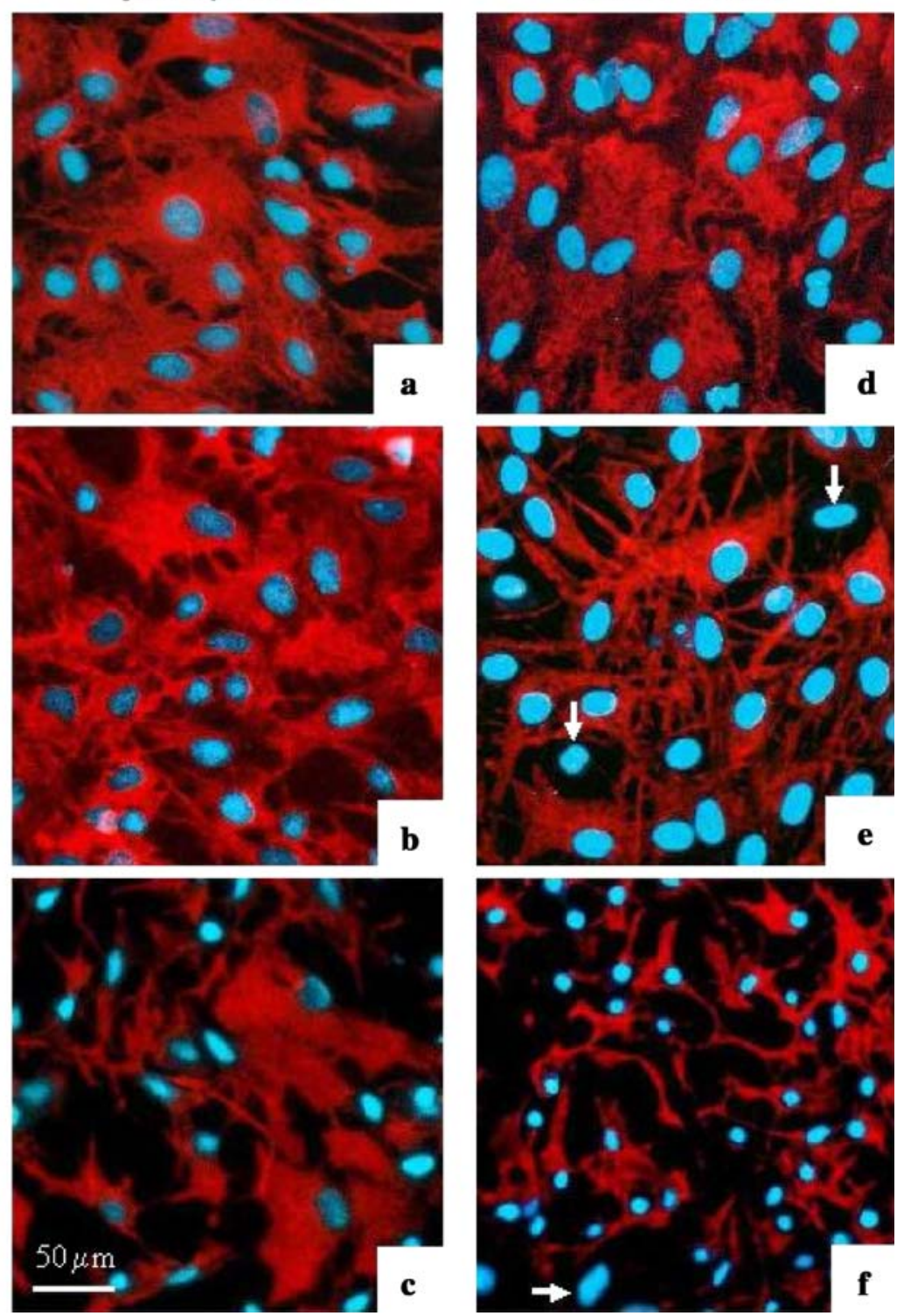

respective role in CNS disorders (Dawson et al. 1994; Aschner 1998; Sanfeliu et al. 1999; Streit et al. 1999; Costa et al. 2002; Vairano et al. 2004). The flavonoid rutin and its aglycone quercetin have chemopreventive activity in a variety of colonic cancer cell lines and in animal models (Deschner et al. 1991; Lipkin et al. 1999; Yang et al. 2000; Dihal et al. 2006). This inhibitory effect was also recently demonstrated in C6 rat glioblastoma cells treated with quercetin (TJ Chen et al. 2006). Considering that the cytotoxic properties of an antineoplastic drug may affect not only neoplasic cells but also normal tissue cells surrounding the neoplasm, it is important to investigate its effects on normal neural cells. In the present work, the biological activity of the flavonoid rutin was assessed to test its effects on these glial cells. Astrocyte primary cultures and astrocyte/microglial mixed primary cultures, both derived from rat cerebral cortex, were exposed to rutin at concentrations of 50 and $100 \mu \mathrm{mol} / \mathrm{L}$, previously shown to be efficient on GL-15 human glioblastoma cells (Silva et al. 2002), and the effects on cell viability and reactivity were investigated. 

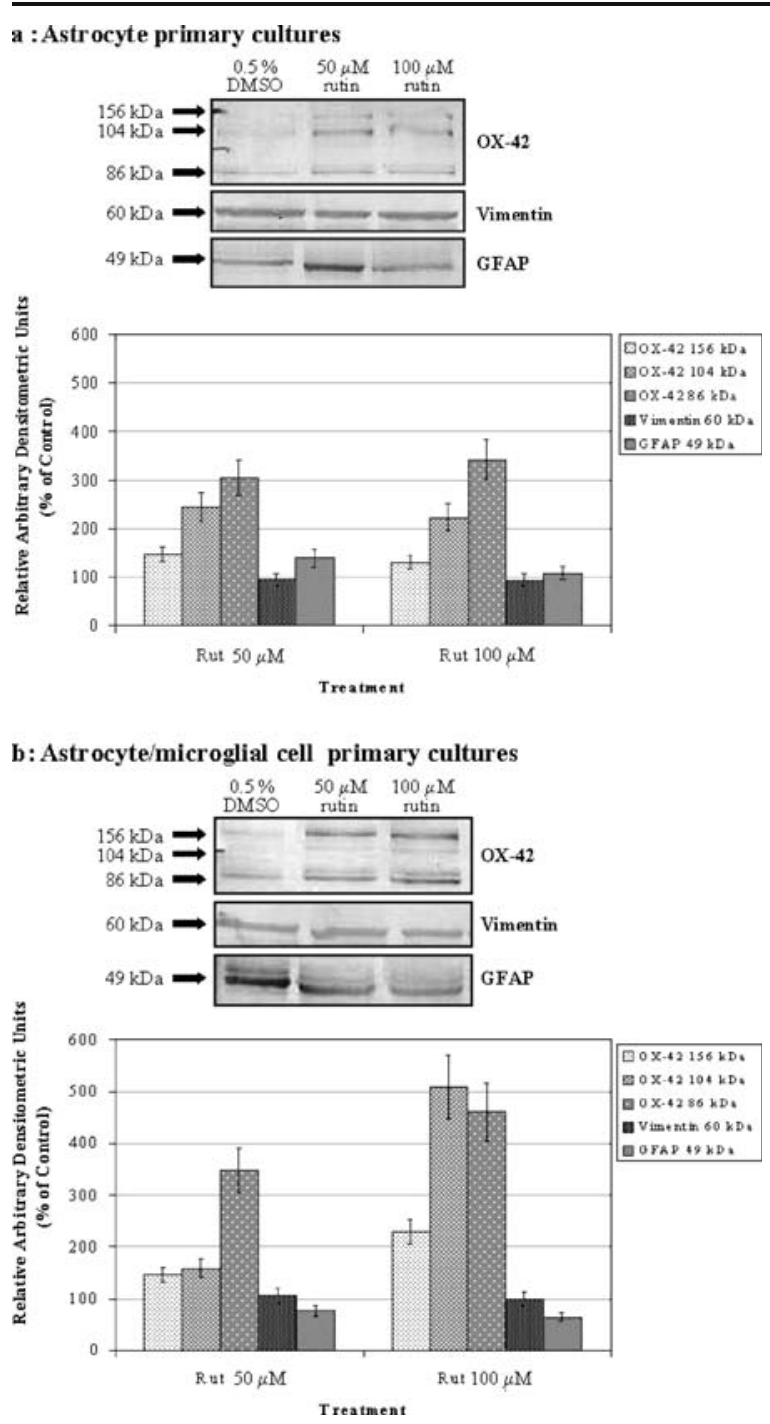

Fig. 5 Western blot analysis of OX-42, vimentin, and GFAP protein expression from astrocyte primary cultures (a) and from astrocyte/microglial cell primary cultures (b), in control conditions (0.5 DMSO) and treated with rutin (50 and $100 \mu \mathrm{mol} / \mathrm{L})$ for $24 \mathrm{~h}$. Samples containing $10 \mu \mathrm{g}$ of total protein were electrophoretically separated through $10 \%$ polyacrylamide gel containing $0.1 \%$ SDS in running buffer. This result is representative of three independent experiments. Histograms represent the relative expression of OX42, vimentin, and GFAP

The cleavage of the tetrazolium ring in MTT involves the mitochondrial succinate dehydrogenase and depends on the activity of the respiratory chain and the redox state of the mitochondria. Cytotoxicity on glial cells after short exposure $(24 \mathrm{~h})$ to 50 or $100 \mu \mathrm{mol} / \mathrm{L}$ rutin was not evidenced by the MTT test. However, since some flavonoids can reduce MTT (Bruggisser et al. 2002; Peng et al. 2005), rutin could interfere and mask the data obtained using the MTT assay. Hence, we used another useful parameter to investigate cell toxicity in vitro, the LDH activity in the culture medium. We observed that although MTT assay showed no toxicity on glial cells, the treatment with $100 \mu \mathrm{mol} / \mathrm{L}$ rutin for $24 \mathrm{~h}$ induced a significant increase in LDH activity on the culture medium of both culture systems, indicating loss of membrane stability that may culminate in cellular death.

Glial cells have important functions that impact neuronal cell health and integrity (Coyle and Schwarcz 2000). Glial fibrillary acidic protein (GFAP) is a major protein of astrocyte intermediate filaments and a specific marker for these cells. We first observed that exposure of glial cells to the flavonoid rutin clearly induced astrocyte structural changes in both culture systems. After treatment with the lowest rutin concentration tested $(50 \mu \mathrm{mol} / \mathrm{L})$, the flat, polygonal GFAP-positive astrocytes begun to contract their cell bodies and transform into cells with short, thick processes. This phenomenon was associated with an increase in the steady-state level of GFAP protein, as revealed by western immunoblot. These changes in the astroglial phenotype associated with an overexpression of GFAP illustrate astroglial reactivity (astrogliosis). While an increase in GFAP production may be a sign of astrogliosis, reactive injury, and even neurodegeneration (Tardy 1991; Coyle and Schwarcz 2000; Costa et al. 2002), a decrease in its levels may signify abnormal synaptogenesis and neurotransmission (O'Callaghan 1991; Rajkowska et al. 2002). In effect, the astrocytes reacted to the highest dose of rutin $(100 \mu \mathrm{mol} / \mathrm{L})$ with a strong cell body retraction. Moreover, a reduction of GFAP expression was also observed in mixed primary cultures by immunocytochemistry and blot. As an increase in LDH activity in the culture medium was also evident in this condition, taken together these results suggest that, besides gliosis, a phenomenon of cytotoxicity may be induced by rutin at the highest concentration adopted.

Microglia, the resident immune cells of the brain, functions similarly to tissue macrophages in other organs, serving as tissue phagocytes (when required) and constituting the first line of defense against invading pathogens and other challenges (Dickson et al. 1993; Giulian et al. 1994; Streit et al. 1999; GonzalezScarano and Baltuch 1999). Activated microglia have been observed to convert into small round cells without processes, expressing OX-42 (Streit et al. 1988; Salimi 
Table 1 The effects of rutin on TNF $\alpha$ and NO levels in the culture medium of astrocyte primary cultures (APC) and mixed primary cultures (MPC)

\begin{tabular}{lccccc}
\hline Treatment & \multicolumn{2}{l}{ TNF $\alpha(\mathrm{pg} / \mathrm{ml})$} & & \multicolumn{2}{l}{ NO $(\mathrm{mmol} / \mathrm{L})$} \\
\cline { 2 - 3 } \cline { 5 - 6 } & APC & MPC & APC & MPC \\
\hline $0.5 \%$ DMSO & $107.60 \pm 39.74$ & $614.89 \pm 33.60$ & & $6.90 \pm 3.13$ & $6.79 \pm 2.90$ \\
$50 \mu \mathrm{mol} / \mathrm{L}$ rutin & $67.45 \pm 29.39$ & $1565.79 \pm 21.12^{*}$ & & $5.70 \pm 2.24$ & $8.57 \pm 5.70$ \\
$100 \mu \mathrm{mol} / \mathrm{L}$ rutin & $161.79 \pm 32.73^{*}$ & $2336.76 \pm 54.75^{*}$ & & $9.79 \pm 4.71$ & $44.54 \pm 9.79^{*}$ \\
\hline
\end{tabular}

* Statistically significant differences compared to controls, $p<0.05$.

and Humpel 2002). An enhanced number of OX-42positive microglia cells, and an increase in the OX-42 protein level illustrated by immunocytochemistry and by western blot were evidenced in MPC. This observation indicates that rutin can also induce microgliosis. This effect appeared enhanced in the presence of the highest concentration of rutin $(100 \mu \mathrm{mol} / \mathrm{L})$.

Molecules and pathways associated with immune or inflammatory responses have been identified in the CNS and are activated in various physiological and/or pathological conditions (Benveniste 1998; Allan and Rothwell 2001). In particular, the expression of the key pro-inflammatory cytokines, IL-1 $\beta$ and/or TNF $\alpha$, has been implicated as early signals that lead to gliosis. However, in vitro and in vivo studies have been suggested that there is not an obligatory role for inflammatory mediators in the initiation of astroglial responses to CNS injury (for review see Little and O'Callaghan 2001). We observed that, besides gliosis, the treatment of mixed glial cell cultures with 50 or $100 \mu \mathrm{mol} / \mathrm{L}$ rutin induced a significant increase in $\mathrm{TNF} \alpha$ levels in the culture medium, whereas in astrocyte primary cultures, this effect was only observed in the presence of the highest rutin concentration $(100 \mu \mathrm{mol} / \mathrm{L})$. Considering that at both rutin concentrations $\mathrm{TNF} \alpha$ release was accompanied by clustering of OX-42-microglia, these findings indicate that, in our system, activated microglia might be the main source of $\mathrm{TNF} \alpha$ in response to this flavonoid. However, the role of this cytokine in astrocyte and microglia responses to rutin remains to be investigated.

Among several factors released by activated glia, NO seems to play a critical role in stress-induced brain damage (Gebicke-Haerter 2001; Manning et al. 2001; Nicholson et al. 2004; Dimayuga et al. 2007). Although production of nitric oxide (NO) is absent in resting glial cells, it can be induced by the conversion of L- arginine to L-citrulline, catalyzed by the induc- ible nitric oxide synthase (iNOS). In this study, in control conditions, similar nitrite levels were observed in the culture medium for both glial primary cultures systems. No significant changes in nitrite levels were observed either in the culture medium of astrocytes treated with 50 or $100 \mu \mathrm{mol} / \mathrm{L}$ rutin or in mixed glial cell cultures treated with $50 \mu \mathrm{mol} / \mathrm{L}$ rutin. However, $24 \mathrm{~h}$ treatment of the astrocyte/microglial cell mixed cultures with this flavonoid at $100 \mu \mathrm{mol} / \mathrm{L}$ induced a significant increase in nitrite production, but not in astrocyte primary cultures, possibly indicating microglial activation. Although NO can induce the expression of GFAP after exposure to the toxin LPS (Brahmachari et al. 2006) we found a predominantly cytotoxic response after exposure of mixed culture to $100 \mu \mathrm{mol} / \mathrm{L}$ rutin. This may be the reason for the decrease in the expression of GFAP observed in these conditions. The antioxidant and anti-inflammatory properties of many flavonoids have been described, and in the CNS the polyphenolic flavonoid baicalein is a good example (Lin and Shieh 1996; YC Chen et al. 2001). It has been demonstrated that this flavonoid inhibits NO production in primary microglia and the murine BV-2 microglial cell line, which is associated with the antioxidant potential (CJ Chen et al. 2004). In a study performed on rat C6 glioma cells (Zieliòska et al. 2003), quercetin, the rutin aglycone, but not rutin, tested in a concentration range of $10-100 \mu \mathrm{mol} /$ $\mathrm{L}$, was able to protect $\mathrm{C} 6$ cells from cytotoxicity and lipid peroxidation. Furthermore, these authors also demonstrated that cytoprotective concentrations of quercetin proved to be cytotoxic themselves. Cytotoxicity of quercetin was also observed by Nakayama et al. (1993) but not by Aherne and O'Brien (1999). This discrepancy might be due to differing vulnerability of the various cell types investigated or to differences in the availability of rutin and quercetin in the cellular in vitro systems used. Despite the fact that 
we did not demonstrate any inhibition of NO production by the flavonoid rutin, its antioxidative properties on glial cells may not be excluded, and new experiments, in toxin-stimulated models, may be developed to elucidate this question.

The results presented here demonstrate that rutin has a direct effect on glial cells in vitro, inducing activation of astrocytes and microglia, TNF $\alpha$ release, and iNOS induction. The role of microglia reactivity in the initiation of the response or in determining the progression of the response via cell-cell interactions remains to be determined, as well as its consequences in the full process of toxicity. Since activation of glia may be neuroprotective or neurotoxic (Vilhardt 2005), the impact of the observed effects on their neuronal partner remains to be investigated.

Acknowledgments This work was supported by grants from Fundação de Amparo à Pesquisa do Estado da Bahia (FAPESB), and Banco do Nordeste do Brasil (BNB). We gratefully acknowledge the research support provided by Programa de Pós-Graduação em Imunologia - UFBA, and Fundação Coordenação de Aperfeiçoamento de Pessoal de Nível Superior (CAPES).

\section{References}

Aherne AS, O'Brien NM. Protection by the flavonoids myricetin, quercetin, and rutin against hydrogen peroxide-induced DNA damage in Caco-2 and Hep G2 cells. Nutr Cancer 1999;34:160-6.

Allan SM, Rothwell NJ. Cytokines and acute neurodegeneration. Nat Rev Neurosci 2001;2:734-44.

Aloisi F. Immune function of microglia. Glia 2001;36:165-79.

Aschner M. Astrocytes as mediators of immune and inflammatory responses in the CNS. Neurotoxicology 1998;19 (2):269-82.

Benveniste EN. Cytokine actions in the central nervous system. Cytokine Growth Factor Rev 1998;9:259-75.

Brahmachari S, Fung YK, Pahan K. Induction of glial fibrillary acidic protein expression in astrocytes by nitric oxide. J Neurosci 2006;26(18):4930-9.

Bruggisser R, von Daeniken K, Jundt G, Schaffner W, Tullberg-Reinert H. Interference of plant extracts, phytoestrogens and antioxidants with the MTT tetrazolium assay. Planta Med 2002;68:445-8.

Chen YC, Shen SC, Chen LG, Lee TJF, Yang LL. Wogonin, baicalin, and baicalein inhibition of inducible nitric oxide synthase and cyclooxygenase- 2 gene expression induced by nitric oxide synthase inhibitors and lipopolysaccharide. Biochem Pharmacol 2001;61:1417-27.

Chen CJ, Raung SL, Liao SL, Chen SY. Inhibition of inducible nitric oxide synthase expression by baicalein in endotoxin/ cytokine-stimulated microglia. Biochem Pharmacol 2004;67 (5):957-65.
Chen TJ, Jeng JY, Lin CW, Wu CY, Chen YC. Quercetin inhibition of ROS-dependent and -independent apoptosis in rat glioma C6 cells. Toxicology 2006;223:113-26.

Cookson MR, Pentreath VW. Alterations in the glial fibrillary acidic protein content of primary astrocyte cultures for evaluation of glial cell toxicity. Toxicol In Vitro. 1994;8 (3):351-9.

Costa SL, Planchenault T, Charrière-Bertrand C, et al. Astroglial permissivity for neurotic outgrowth in neuronastrocyte cocultures depends on regulation of lamini bioavailability. Glia 2002;37:105-13.

Coyle JT, Schwarcz R. Mindglue: implications of glial cell biology for psychiatry. Arch Gen Psychiatry 2000;57 (1):90-3.

Dawson VL, Brahmbhatt JA, Mong JA, Dawson TM. Expression of inducible nitric oxide synthase causes delayed neurotoxicity in primary mixed neuronal-glia cortical cultures. Neuropharmacology 1994;33(11):1425-30.

Deschner EE, Ruperto J, Wong G, Newmark HL. Quercetin and rutin as inhibitors of azoxymethanol-induced colonic neoplasia. Carcinogenesis 1991;12:1193.

Dickson DW, Lee SC, Mattiace LA, Yen SH, Brosnan C. Microglia and cytokines in neurological disease, with special reference to AIDS and Alzheimer's disease. Glia 1993;7:75-83.

Dihal AA, de Boer VC, van der Woude H, et al. Quercetin, but not its glycosidated conjugate rutin, inhibits azoxymethane-induced colorectal carcinogenesis in F344 rats. J Nutr 2006;136:2862-7.

Dimayuga FO, Wang C, Clark JM, Dimayuga ER, Dimayuga VM, Bruce-Keller AJ. SOD1 overexpression alters ROS production and reduces neurotoxic inflammatory signaling in microglial cells. J Neuroimmunol 2007;182:89-99.

Gebicke-Haerter PJ. Microglia in neurodegeneration: molecular aspects. Microsc Res Tech 2001;54:47-58.

Giulian D, Leara J, Li J, Keenen C. Phagocytic microglia release cytokines and cyttoxins that regulate the survival of astrocytes and neurons in culture. Neurochem Int 1994;25:227-32.

Gonzalez-Scarano F, Baltuch G. Microglia as mediators of inflammatory and degenerative diseases. Annu Rev Neurosci 1999;22:219-40.

Hansen MB, Nielsen SE, Berg K. Re-examination and further development of a precise and rapid dye method for measuring cell growth/cell kill. J Immunol Methods 1989;119:203-10.

Havsteen BH. Biochemical and medical significance of flavonoids. Pharmacol Ther 2002;96:67-202.

Higuchi T, Shibata H, Nakada T, Sato Y. Pharmaceutical composition for treatment of infection with drug resistant bacterium and disinfectant. U.S. Pat Appl 20060229262.

Janbaz KH, Saeed AS, Gilani AH. Protective effect of rutin on paracetamol- and $\mathrm{CCl}_{4}$-induced hepatotoxicity in rodents. Fitoterapia 2002;73:557-63.

Lambev I, Belcheva A, Zhelyazkov D. Flavonoids with antioxidant action (naringin and rutin) and the release of mastocytic and nonmastocytic histamine. Acta Physiol Pharmacol Bulg 1980a;6:70-5.

Lambev I, Krushkov I, Zheliazkov D, Nikolov N. Antiexudative effect of naringin in experimental pulmonary edema and peritonitis. Eksp Med Morfol 1980b;19:207-12. 
Lin CC, Shieh DE. The anti-inflammatory activity of Scutellaria rivularis extracts and its active components, baicalin, baicalein, and wogonin. Am J Chin Med 1996;24:31-6.

Lipkin M, Reddy B, Newmark H, Lamprecht SA. Dietary factors in human colorectal cancer. Annu Rev Nutr 1999; 19:545-86.

Little AR, O'Callaghan JP. Astrogliosis in the adult and developing CNS: is there a role for proinflammatory cytokines? Neurotoxicology 2001;22:607-18.

Lowry OH, Rosenbrough NJ, Farr AL, Randall RJ. Protein measurement with the folin phenol reagent. J Biol Chem 1951;193:265-75.

Manning P, Cookson MR, McNeil CJ, Figlewicz D, Shaw PJ. Superoxide-induced nitric oxide release from cultured glial cells. Brain Res 2001;911:203-10.

Markhan KR. Techniques of flavonoid identification. London: Academic Press; 1982.

Moises HW, Zoega T, Gottesman IL. The glial growth factors deficiency and synaptic destabilization hypothesis of schizophrenia. BMC Psychiatry 2002;2(1):8.

Nakayama T, Yamada M, Osawa T, Kawakishi S. Suppression of active oxygen-induced cytotoxicity by flavonoids. Biochem Pharmacol 1993;45:265-7.

Nicholson TE, Dibb S, Renton KW. Nitric oxide mediates an LPS-induced depression of cytochrome P450 (CYP1A) activity in astrocytes. Brain Res 2004;1029:148-54.

O'Callaghan JP. Assessment of neurotoxicity: use of glial fibrillary acidic protein as a biomarker. Biomed Environ Sci 1991;4:197-206.

Peng L, Wang B, Ren P. Reduction of MTT by flavonoids in the absence of cells. Colloids Surf B Biointerfaces 2005; 45:108-11.

Raivich G, Jones LL, Werner A, Blathmann H, Doetschmann T, Kreutzberg GW. Molecular signals for glial activation: pro- and anti-inflammatory cytokines in the injured brain. Acta Neurochir 1999;73:21-30.

Rajkowska G, Miguel-Hidalgo JJ, Makkos Z, Metzer H, Overholser J, Stockmeier C. Layer-specific reductions in GFAP-reactive astroglia in the dorsolateral prefrontal cortex in schizophrenia. Schizophr Res 2002;57(2-3):127-38.

Raven PH, Evert RF, Eichorn SE. Biologia Vegetal. 6th ed. Rio de Janeiro: Guanabara Koogan; 2001. p. 34-53.

Ridet JL, Malhotra SK, Privat A, Gage FH. Reactive astrocytes: cellular and molecular cues to biological function. Trends Neurosci 1997;20:570-7.

Rosenfeld G. Corante pancrômico para hematologia e citologia clínica: nova combinação dos componentes de May Grunwald e do Giemsa num só corante de emprego prático. Mem Inst Butantã 1947;20:329-35.

Salimi K, Humpel C. Down regulation of complement receptor 3 and major histocompatibility complex I and II antigen- like immunoreactivity accompanies ramification in isolated rat microglia. Brain Res 2002;946:283-9.

Sanfeliu C, Crisòfol R, Torán N, Rodrigues-Farré E, Kim SU. Use of human central nervous system cell cultures in neurotoxicity testing. Toxicol In Vitro. 1999;13(4-5):753-9.

Schroeter H, Rose S, Jenner P, Rice-Evans CA. Uptake and metabolism of epicatechin and its access to the brain after oral ingestion. Free Radic Biol Med 2002;33:1693-702.

Silva AR, Hughes JB, Barreto RA, et al. The flavonoid rutin, extracted from Dimorphandra mollis, inhibits proliferation and stimulates differentiation of GL-15 human glioblastoma cells. In: XVII Simpósio de Plantas Medicinais do Brasil, Cuiabá-MT. Anais do XVII Simpósio de Plantas Medicinais do Brasil. 2002.

Silva AMM, Silva AR, Pinheiro AM, et al. Alkaloids from Prosopis juliflora leaves induce glial activation, cytotoxicity and stimulate NO production. Toxicon. [In Press. Accepted Manuscript. Available online 17 August 2006.

Streit WJ, Graeber MB, Kreutzberg GW. Functional plasticity of microglia: a review. Glia 1988;5:301-7.

Streit WJ, Walter AS, Pennel NA. Reactive microgliosis. Prog Neurobiol 1999;57:563-81.

Takasato Y, Rapoport SI, Smith QR. An in situ brain perfusion technique to study cerebrovascular transort in the rat. Am J Physiol 1984;247:H484-93.

Tardy M. Astrocyte et homeostasie. Med Sci (Paris) 1991;8 (7):799-804.

Vairano M, Graziani G, Tentori L, Tringali G, Navarra P, Russo CD. Primary cultures of microglial cells for testing toxicity of anticancer drugs. Toxicol Lett 2004;148:91-4.

Vilhardt F. Microglia: phagocyte and glia cell. Int J Biochem Cell Biol 2005;37:17-21.

Wang Z, Li D, Liang Y, Wang D, Cai N. Activation of astrocytes by advanced glycation end products: cytokines induction and nitric oxide release. Acta Pharmacol Sin 2002;23(11):974-80.

Yang K, Lamprecht AS, Liu Y, et al. Chemoprevention studies of the flavonoids quercetin and rutin in normal and azoxymethane-treated mouse colon. Carcinogenesis 2000; 21:1655-60.

Youdim KA, Dobbie MS, Kuhnle G, Proteggente AR, Abbott NJ, Rice-Evans C. Interaction between flavonoids and the blood-brain barrier: in vitro studies. J Neurochem 2003;85 (1):180-92.

Youdim KA, Shukitt-Hale B, Joseph JA. Flavonoids and the brain: interactions at the blood-brain barrier and their physiological effects on the central nervous system. Free Radic Biol Med 2004;37(11):1683-93.

Zieliňska M, Gülden M, Seibert H. Effects of quercetin and quercetin-3-O-glycosides on oxidative damage in rat $\mathrm{C} 6$ glioma cells. Environ Toxicol Pharmacol 2003;13:47-53. 